\title{
Studies on antimicrobial activities of endophytic bacteria isolated from Neem tree (Azadirachta indica)
}

\author{
Duong Nhat Linh ${ }^{1 *}$, Bui Van Thien ${ }^{1}$, Tran Thi A Ni², Nguyen Thanh Duy ${ }^{3}$, Nguyen Van \\ Minh $^{1}$, Tran Cat Dong ${ }^{4}$ \\ ${ }^{1}$ Ho Chi Minh City Open University, Vietnam \\ ${ }^{2}$ Midoli Co., ltd, Vietnam \\ ${ }^{3}$ University of San Francisco, USA \\ ${ }^{4}$ University of Medicine and Pharmacy at Ho Chi Minh City, Vietnam \\ *Corresponding author: linh.dn@ou.edu.vn
}

\begin{abstract}
ARTICLE INFO
ABSTRACT

DOI: $10.46223 / \mathrm{HCMCOUJS.}$

tech.en.10.1.362.2020

Received: August $19^{\text {th }}, 2019$

Revised: December 27 $7^{\text {th }}, 2019$

Accepted: December $28^{\text {th }}, 2019$

Keywords:

Azadirachta indica A. Juss, bacillus subtilis, Candida albicans, endophytic bacteria, trichophyton rubrum

The objective of this study is to isolate endophytic bacteria from Azadirachta indica (neem). We isolated 7 strains of endogenous bacteria from the neem tree. By investing the antifungal and antibacterial activities of endophytic bacteria in $A$. indica by well diffusion agar method, we noticed there was KT2 strain which resisted to Salmonella typhi and Staphylococcus aureus $(10.67 \pm 0.33 \mathrm{~mm}$ and $9.67 \pm 0.33 \mathrm{~mm})$, KT3 strain showed the inhibitory activity to three human pathogenic fungal (Candida albicans, Trichophyton mentagrophytes, Trichophyton rubrum), two strains (KT1, KT2) which resisted to $C$. albicans and $T$. rubrum. According to Cowan and Steel's manual, the result of biochemical identification showed that the KT2 strain was the Bacillus subtilis species.
\end{abstract}

\section{Introduction}

Endophytes are endosymbionts, including bacteria or fungi that live in the intercellular spaces or, sometimes, in the intra-cellular spaces of a plant without causing the apparent disease to the host plant (Compant, Duffy, Nowak, Clement, \& Barka, 2005). Endophytes are found in all the species of plants today. They use nutrients from the host plant tissues to grow, but they benefit to the host by enhancing host growth or improve the plant's resistance to insects, plant's pathogens and herbivores by producing metabolites exhibiting a variety of biological activities against different pathogens (Arun, Ashok, \& Rajesh, 2011). Many studies have emphasized the endophytes from medicinal plants and their applications in different areas (Garcia, Rhoden, Rubin-Filho, Nakamura, \& Pamphile, 2012). Recently, many endophytic bio-active metabolites, possessing a wide variety of biological activities such as an antibiotic, antiviral, anticancer, anti-inflammatory, antioxidant, etc. have been identified (Strobel \& Daisy, 2003). Roy and Banerjee (2010) investigated the compound secreted from 4 endogenous bacteria from Vinca rosea that resisted to bacterial and fungal pathogens. One of the isolated endophytes 
produced had potential antimicrobial activity against Bacillus cereus, Klebsiella pneumoniae and Escherichia coli (Roy \& Banerjee, 2010). In 2014, Bintang, Kusumavati, Safira, Pasaribu, and Sidhartha isolated the endogenous BS1 strain from Piper betle (L.) leaves that have been demonstrated the antibacterial ability against several pathogenic bacteria such as E. coli, B. cereus, and Staphylococcus aureus. There was a report of endophytic bacteria isolated from medicinal plant Phyllanthus niruri having anticandidal activity against Candida albicans (Chellaram, 2015). Antimicrobial potentials were reported for endophytic bacteria which isolated from the medicinal plants: Phyllodium pulchellum (Benth) Desv, Tinospora cordifolia Miers, Memecylon edule Roxb and Dipterocarpus tuberculatus Roxb (Bhoonobtong, Sawadsitang, Sodngam, \& Mongkolthanaruk, 2012).

Neem or nimtree (Azadirachta indica A. Juss) is a divine tree mainly cultivated in the Indian subcontinent, belonging to the botanical family Meliaceae (Upma, Ashok, Pankaj, \& Tarun, 2011). Every part of neem was used in medicines for centuries and thus was commercially exploitable. It is also considered to be a/ to become a/as a natural source for medicines and industrial products. The barks, seeds, leaves, fruit, extracts, and oils of the neem trees contain pharmacological substances which offer some impressive therapeutic applications like antimicrobial, anti-pyretic, and anti-inflammatory, anti-tumor, and anti-helminthic activities (Shenpagam, Kanchana, Sinduja, \& Sandhya, 2012). Therefore, endophytes from neem trees have the potential for producing valuable metabolites and contributing to the pharmacological activities of their host.

This study was aimed to isolate endophytic bacteria from neem tree parts and study the antibacterial activity of these endophytes against human pathogenic bacteria and fungi.

\section{Materials and method}

\subsection{Materials}

Neem tree (Azadirachta indica A. Juss) was identified based on local names, morphological descriptions, and characteristics of flowers, fruits, and seeds by Department of Botany of the University of Science, Ho Chi Minh City.

Fresh and healthy leaves and barks of neem trees were collected in Binh Thuan province and Vung Tau province, Vietnam. Samples were used for isolation of endophytic bacteria within $24 \mathrm{~h}$.

Bacterial pathogenic strains and dermatophytic fungi were provided by the Microbiology Laboratory of Ho Chi Minh City Open University and Laboratory of Pharmaceutical Biotechnology, Department of Microbiology, Ho Chi Minh City University of Medicine and Pharmacy: Salmonella typhi ATCC 19214, Pseudomonas aeruginosa ATCC 15692, Staphylococcus aureus ATCC 25922, Escherichia coli ATCC 25922, Candida albicans, Trichophyton rubrum, Trichophyton mentagrophytes, and Microsporum gypseum.

\subsection{Isolation of endophytic microorganism}

Fresh samples were washed under running tap water, cut into small segments $(2-4 \mathrm{~cm})$. The sample was sterilized with $95 \%$ ethanol for 2 mins followed by 4-6\% sodium hypochlorite 
for 90 seconds then washed again in $95 \%$ ethanol for 30 seconds, and finally rinsed with sterile water in 5 times. After that, those plant parts were gently washed in autoclaved with/under distilled water and were soaked in autoclaved tissue paper (Suryanarayanan, Wiltlinger, \& Faeth, 2005). To confirm that the surface of the sample was effectively sterilized, $0.1 \mathrm{ml}$ of the final rinse was spread on nutrient agar plates and incubated at $37^{\circ} \mathrm{C}$ for $24 \mathrm{~h}$ then checked for possible microbial growth.

The sterilized samples were placed on TSA medium for 3 days and monitored every day to check the growth of endophytic colonies from the leaves and barks. Characterization of the bacteria was done accordingly to its morphology and by Gram-staining. After that, a single colony was transferred into TSB medium and incubated at $37^{\circ} \mathrm{C}$ for $24 \mathrm{~h}$ and then stored at $20^{\circ} \mathrm{C}$ for further works.

\subsection{Antibacterial test}

The antibacterial activity of endophytic bacteria was screened by the agar diffusion method. A single colony of pathogens was grown in $5 \mathrm{ml}$ of nutrient broth at $37^{\circ} \mathrm{C}$ for $4-6 \mathrm{~h}$, the resulting cultures were diluted into a density of $10^{8} \mathrm{CFU} / \mathrm{mL}$ (determined by OD600 of 0.08 0.1 ) and spread on MHA plates using sterile cotton swabs then holes with a diameter of $8 \mathrm{~mm}$ were punched on the surface. Isolated endophytic bacteria were grown in $30 \mathrm{ml}$ of the Nutrient broth $(\mathrm{NB})$ at $32^{\circ} \mathrm{C}$ on a rotary shaker (150rpm). After 5 days, cultures were centrifuged at $8000 \mathrm{rpm}$ for $8 \mathrm{mins}$ at $4^{\circ} \mathrm{C}$, the supernatant was filtered with $0.2 \mu \mathrm{m}$ membrane and used to fill the holes on prepared pathogenic plates. The sterile nutrient broth was used as a control. After incubation at $37^{\circ} \mathrm{C} / 24 \mathrm{~h}$, the diameter of inhibitory zones around each hole was measured (Roy \& Banerjee, 2010).

Similarly, antifungal activity of endophytic bacteria was tested by using spore's suspension $\left(10^{6}\right.$ spores $\left./ \mathrm{mL}\right)$ of testing fungi spread over the surface of the PDA plates. The antifungal test plates were incubated at $27^{\circ} \mathrm{C}$ for $3-5$ days. After incubation, the diameter of inhibitory zones around each hole was measured (Kumar, Saini, \& Shrivastava, 2009).

The results were processed and statistically analyzed with Stagraphic Plus 3.0 software.

\subsection{Endophytic bacteria identification}

The selected strains were identified by following Cowan and Steel's manual for the identification of medical bacteria (Feltham \& Barrow, 1993).

\section{Results}

\subsection{Isolation of endophytic microorganism}

From 12 neem samples collected in Phan Thiet and Lagi (Binh Thuan province), Vung Tau (Ba Ria - Vung Tau province), 7 endophytic bacterial strains were isolated (6 Grampositive trains and 1 Gram-negative one). In a study by Chandrashekhara, Niranjanraj, Deepak, Amruthesh, and Shetty (2007), 7 endogenous strains were isolated from the stem and root of the neem tree in India, showing that 2 Gram-positive and 5 Gram-negative strains. Singh et al. (2017) isolated 25 endophytic bacteria from neem leaves, and most of them were Gram-positive 
and rod shape. Table 1 shows the number of different strains isolated by location and sample type.

\section{Table 1}

Result endophytic bacteria isolation

\begin{tabular}{lcccc}
\hline & No. of Samples & \multicolumn{3}{c}{ No. of Isolates } \\
\cline { 3 - 5 } & 5 & Bark & Leaves & Total \\
\hline Phan Thiet & 3 & 3 & 1 & 4 \\
\hline Vugi & 4 & 1 & 1 & 2 \\
\hline Total & $\mathbf{1 2}$ & $\mathbf{5}$ & $\mathbf{2}$ & $\mathbf{7}$ \\
Source: Data analysis result of the research & & & & \\
\hline & & & & \\
\end{tabular}

Figure 1. Endophytic bacteria from bark sample on TSA medium

\subsection{Antibacterial test}

Out of 7 isolates, only the strains KT2 had effects against S. typhi and S. aureus, with inhibitory zones diameter of $10.67 \pm 0.33 \mathrm{~mm}$ and $9.67 \pm 0.33 \mathrm{~mm}$, respectively (Table 2). In the Kumar, Antoty, and Rajesh (2015) study, out of 7 endogenous isolates from the neem, only 1 strain showed the activity against methicillin-resistant $S$. aureus (MRSA) but did not against other pathogenic bacteria or Candida albicans. 


\section{Table 2}

The antibacterial activity of culture filtrate of endophytic bacteria (mm)

\begin{tabular}{ccccc}
\hline Isolate & $\begin{array}{c}\text { E. coli } \\
\text { ATCC 25922 }\end{array}$ & $\begin{array}{c}\text { P. aeruginosa } \\
\text { ATCC 15692 }\end{array}$ & $\begin{array}{c}\text { S. aureus } \\
\text { ATCC 25922 }\end{array}$ & $\begin{array}{c}\text { S. typhi } \\
\text { ATCC 19214 }\end{array}$ \\
\hline KT1 & - & - & - & - \\
KT2 & - & - & $9.67 \pm 0.33$ & $10.67 \pm 0.33$ \\
KT3 & - & - & - & - \\
KT4 & - & - & - & - \\
KT5 & - & - & - & - \\
KL1 & - & - & - & - \\
KL2 & - & - & - & - \\
\hline
\end{tabular}

Note: (-) negative

Source: The researcher's data analysis

\subsection{Antifungal test}

The result showed that endogenous strains KT1, KT2 and KT3 had the activity against C. albicans and $T$. rubrum, and strain KT3 also showed the inhibitory activity to $T$. mentagrophytes (Table 3 and Figure 2).

\section{Table 3}

Antifungal activity of filtrate culture endophytic bacterial ( $\mathrm{mm}$ )

\begin{tabular}{ccccc}
\hline Isolate & C.albicans & T. mentagrophytes & T. rubrum & M. gypseum \\
\hline KT1 & $30.33 \pm 0.33^{\mathrm{a}}$ & - & $29.67 \pm 0.33^{\mathrm{a}}$ & - \\
KT2 & $31.33 \pm 0.88^{\mathrm{a}}$ & - & $28.33 \pm 0.33^{\mathrm{b}}$ & - \\
KT3 & $31.33 \pm 0.67^{\mathrm{a}}$ & $30.67 \pm 0.33^{\mathrm{a}}$ & $24.33 \pm 0.67^{\mathrm{a}}$ & - \\
KT4 & - & - & - & - \\
KT5 & - & - & - & - \\
KL1 & - & - & - & - \\
KL2 & - & - & - & - \\
\hline
\end{tabular}

Note: (-) negative

Source: The researcher's data analysis 

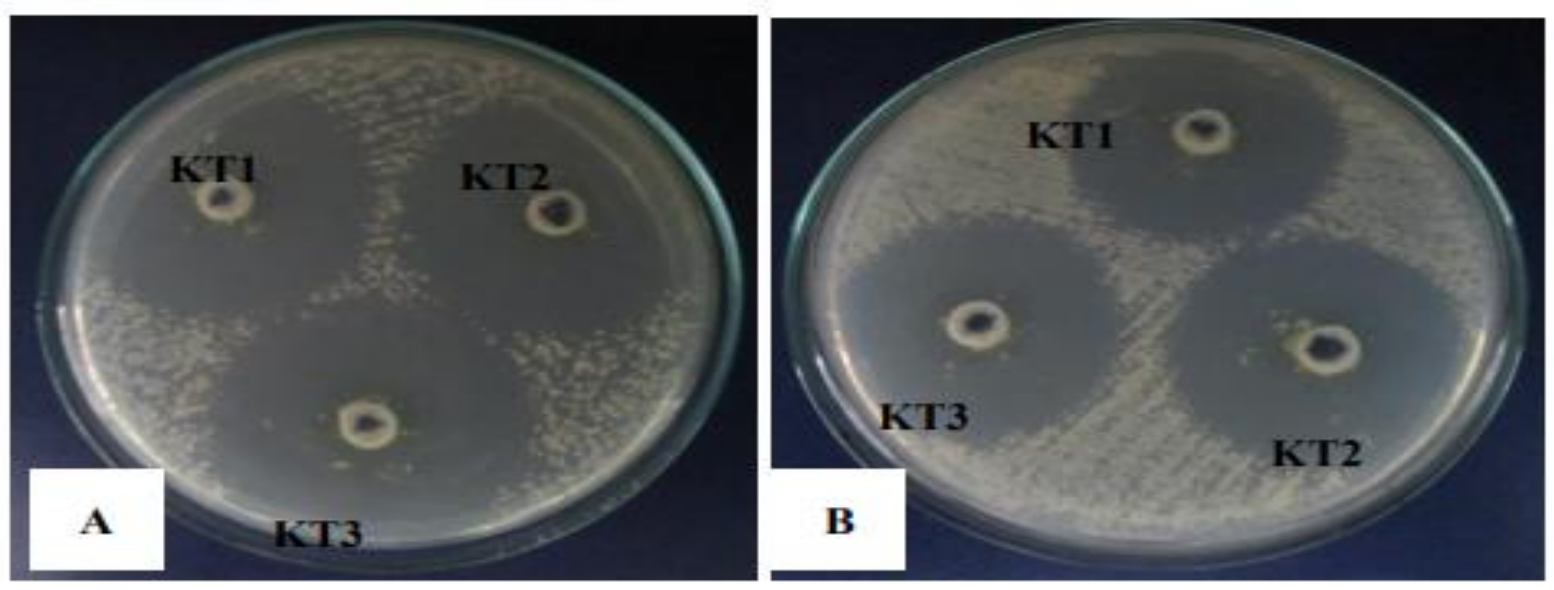

Figure 2. Antifungal activity of endophytic bacteria

Note: Test fungi: A: C. albicans; B: T. rubrum

\subsection{Strain identification}

Throughout the results of the investigation of the antibacterial and antifungal ability of the 7 endogenous bacteria strains, we obtained KT2 strains that had the most inhibitory activity to bacteria. Then, we conducted the identification for the strain KT2 (Feltham \& Barrow, 1993). As a result, the KT2 strain was identified as Bacillus subtilis (85.71\% ID).

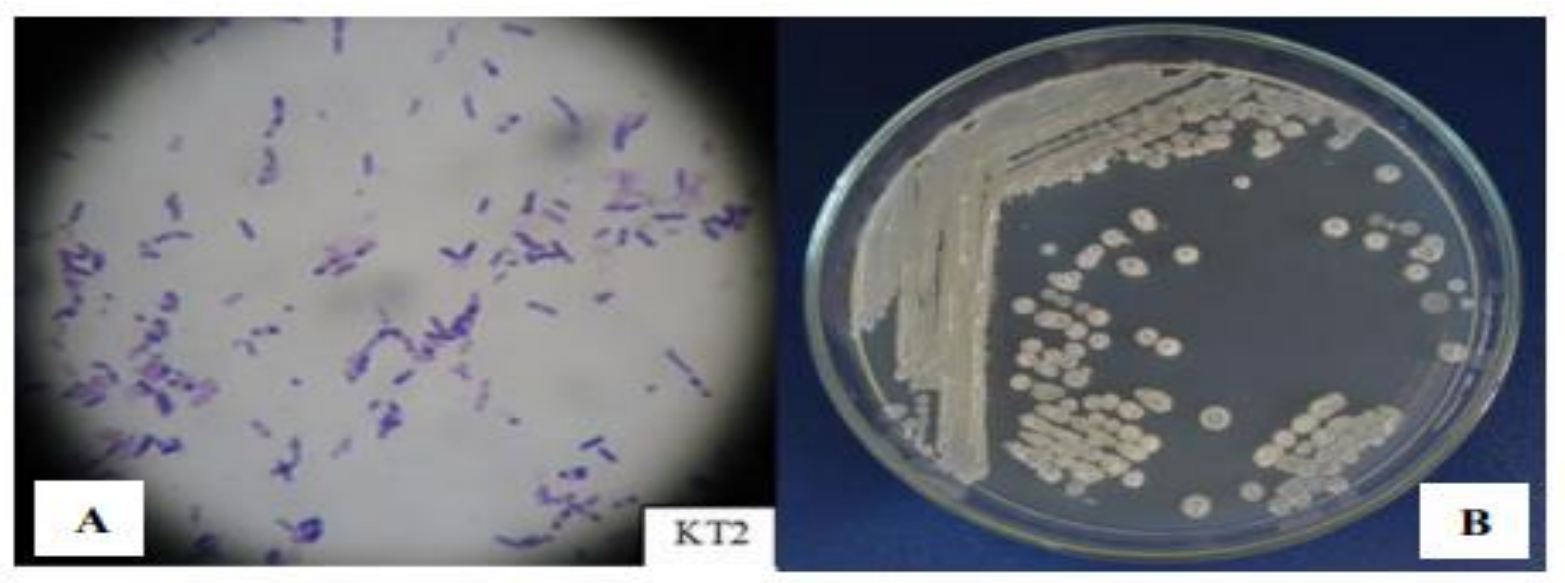

Figure 3. Results of morphological analyses: (A) microscopic view of Gram-stained KT2 (x100) \& (B) Plate culture of the isolate KT2 on nutrient agar

\section{Table 4}

Biochemical identification of KT2 strain

\begin{tabular}{|llllll|}
\hline Catalase & + & Galactose & + & Urease & - \\
\hline Motility & + & Mannose & + & Indol & - \\
\hline
\end{tabular}




\begin{tabular}{|ccllll}
\hline $\mathbf{5 0} \mathbf{C}$ & + & Mellobiose & - & VP & + \\
\hline $\mathbf{1 0 \%} \mathbf{~ N a C l}$ & + & Raffinose & + & Nitrate & + \\
\hline Anaerobic & - & Salicin & + & Casein & + \\
\hline Glucose & + & Xylose & + & Amylase & + \\
\hline Cellobiose & + & Citrate & + & Oxydase & + \\
\hline & & Bacillus subtilis & \\
\hline
\end{tabular}

\section{Discussion}

Microorganisms, especially endophytic, are great potential sources of diverse and structural bioactive compounds. Endogenous bacteria have been found in medicinal plants and weeds. Endophyte bacteria are known as one of bioactive compounds producers such as secondary metabolite compounds with various biological activities. The natural products obtained from endogenous bacteria have been antibacterial, antiviral, anti-cancer, antioxidant and immunosuppressive (Strobel \& Daisy, 2003). Recently, several studies have described endophyte bacteria with biological control activity on several crops as potential sources of antimicrobial metabolites. Ecomycins, pseudomycins are new antibiotics produced by endogenous bacteria such as Pseudomonas viridiflava and endophytic bacteria that produced Ecomycins with anti-fungal activity. In 2009, Verma et al. isolated 55 endogenous actinobacteria from neem which could inhibit 54.4\% of bacterial and fungal activity. Chandrashekhara et al. (2007) isolated 7 endogenous strains from neem in India, including 2 strains of Gram-positive and 5 strains of Gram-negative. Singh et al. (2017) isolated 25 endophytic bacteria from $A$. indica (neem). The microscopic examination revealed that maximum isolates were Gram-positive and rod-shaped. Good antibacterial activity was observed which S. aureus, Streptococcus pyogenes, E. coli, Salmonella typhimurium, and K. pneumoniae. (Singh et al., 2017). This study is also very near to all the above authors.

\section{Conclusion}

The result showed that endophytic strains KT1, KT2 and KT3 from neem tree have strong antimicrobial activities against human pathogens, especially, strain KT2 showed both the antibacterial and anti-fungal activities. Further studies should be carried out to determine the nature and mechanism of active compounds from these strains.

\section{ACKNOWLEDGMENTS}

This work was funded by Ho Chi Minh City Open University. 


\section{References}

Arun, K., Ashok, M., \& Rajesh, S. (2011). Crude oil PAH constitution, degradation pathway and associated bioremediation microflora: An overview. International Journal of Environmental Science and Technology, 7, 1420-1439.

Bhoonobtong, A., Sawadsitang, S., Sodngam, S., \& Mongkolthanaruk, W. (2012). Characterization of endophytic bacteria, Bacillus amyloliquefaciens for antimicrobial agents production. In International Conference on Biological and Life Sciences, IPCBEE. Singapore: IACSIT Press.

Bintang, M., Safira, U. M., Kusumawati, D., Pasaribu, F. H., \& Sidhartha, T. (2014). Analysis of 16S rRNA sequence of Endophytic bacteria isolate BS1 from Piper betle [L.] Stem. In International Conference Agricultural, Environmental and Biological Sciences (AEBS) (pp. 69-70).

Chandrashekhara, Niranjanraj, S., Deepak, S. A., Amruthesh, K. N., Shetty, N. P., \& Shetty, H. S. (2007). Endophytic bacteria from different plant origin enhance growth and induce downy mildew resistance in Pearl Millet. Asian Journal of Plant Pathology, 1(1), 1-11. doi:10.3923/ajppaj.2007.1.11

Chellaram, C. (2015) Screening of Antagonistic Endophytic bacteria from Phyllanthus niruri leaves. International Journal of Pharm Tech Research, 8(2), 230-234.

Compant, S., Duffy, B., Nowak, J., Clement, C., \& Barka, E. A. (2005). Use of plant growth promoting bacteria for biocontrol of plant diseases: Principles, mechanisms of action, and future prospects. Applied Environmental Microbiology, 71(9), 4951-4959.

Feltham, R. K. A., \& Barrow, G. I. (1993). Cowan and Steel's manual for the identification of medical bacteria. Cambridge, UK: Cambridge University Press.

Garcia, A., Rhoden, S. A., Rubin-Filho, C. J., Nakamura, C. V., \& Pamphile, J. A. (2012). Diversity of foliar endophytic fungi from the medicinal plant Sapindus saponaria L. and their localization by scanning electron microscopy. Biological Research, 45(2), 139-148. doi:10.4067/S0716-97602012000200006

Kumar, A. G., Antoty, R. A., \& Rajesh, K. V. (2015). Exploration of endophytic microorganisms from selected medicinal plants and their control potential to multi drug resistant pathogens. Journal of Medicinal Plants Studies, 3(2), 49-57.

Kumar, A., Saini, P., \& Shrivastava, J. N. (2009). Production of peptide antifungal antibiotic biocontrol activity of Bacillus subtilis. Indian Journal of Experimental Biology, 47(1), 57-62.

Roy, S., \& Banerjee, D. (2010). Research article isolation of antimicrobial combound by endophytic bacteria from Vinca rosea. International Journal of Current Research, 5, 4751.

Ryan, R. P., Germaine, K., Franks, A., Ryan, D. J., \& Dowling, D. N. (2008). Bacterial endophyte: Recent development and application. FEMS Microbiology Letter, 278(1), 19. 
Shenpagam, N. H., Kanchana, D. D., Sinduja, G., \& Sandhya. R. (2012). Isolation of endophytic Actinomycetes from medicinal plants and its mutational effect in biocontrol activity. International Journal Pharmaceutical Sciences and Research, 3(11), 4338-4344.

Singh, A. K., Sharma, R. K., Sharma, V., Singh, T., Kumar, R., \& Kumari, D. (2017). Isolation, morphological identification and in vitro antibacterial activity of endophytic bacteria isolated from Azadirachta indica (neem) leaves. Veterinary World, 10(5), 510-516.

Strobel, G., \& Daisy, B. (2003). Bioprospecting for microbial endophytes and their natural products. Microbiology and Molecular Biology Reviews, 67(4), 491-502.

Suryanarayanan, T. S., Wiltlinger, K. S., \& Faeth, H. S. (2005). Endophytic fungi associatied with cacti Arizona. The British Microbiology Society, 109(5), 635-639.

Upma, A., Ashok, K., Pankaj, K., \& Tarun, K. (2011). The nature's gift to mankind: Neem. International Research Journal of Pharmacy, 2(10), 13-15.

Verma, V. C., Gond, S. K., Kumar, A., Mishra, A., Kharwar, R. N., \& Gange, A. C. (2009). Endophytic Actinomycete from Azadirachta indica A. Juss.: Isolation, diversity, and antimicrobial activity. India Journal Microbiology, 57(4), 749-756. 